\title{
An Investigation of the Relationship between Mothers' Traumatic Delivery Perception and Maternal Attachment
}

\section{Annelerde Algılanan Travmatik Doğum Algısı ile Maternal Bağlanma Arasındaki İlişkinin İncelenmesi}

\author{
Iffet Nur Çalışır ${ }^{1}$, Hacer Alan Dikmen * ${ }^{2}$, Kamile Marakoğlu
}

\begin{abstract}
Aim: To investigate the relationship between mothers' traumatic birth perception and maternal attachment. Method: The data for this descriptive and correlational study was collected from 280 mothers of 1 - to 6-month old babies who were treated at family health centers between January and March 2020. The study was completed with 280 mothers. The data were collected using a Personal Information Form, the Maternal Attachment Scale (MAS), and the Traumatic Birth Perception Scale (TBPS). Data were evaluated by median, minimum-maximum values, Spearman correlation analysis, and Kruskal-Wallis analysis. Results: In our study, the median age of the mothers was 27 (17-41) years and the number of living children was 2 (0-6). Pregnancy was planned in $80.7 \%$ of the mothers, 97.1\% had their pregnancy follow-ups regularly, $46.1 \%$ were attended by a midwife during delivery. We found that $71.8 \%$ of the mothers took their babies into their arms and $61.4 \%$ started their first breastfeeding in the first 30 minutes postpartum. The mothers' median score for MAS was 104 (74-104), and the median score for TBPS was 69.5 (0-130). In our study, there was no significant relationship between the mothers' MAS and TBPS median scores according to the correlation analysis result $(\mathrm{r}=-0.031, \mathrm{p}=0.608)$. According to the TBPS, $34.6 \%$ of the mothers had a medium perception of traumatic birth. Conclusion: In our study, it was found that maternal attachment levels of the mothers were high and their perception of traumatic birth was medium. There was no significant relationship between the maternal attachment level of the mothers and their perception of traumatic birth. Accordingly, in future studies, maternal attachment level and perception of traumatic birth can be examined with larger sample groups.
\end{abstract}

Key words: Birth, traumatic birth perception, maternal attachment, midwifery.

\section{ÖZET}

Amaç: $\mathrm{Bu}$ çalışmada annelerde algılanan travmatik doğum algısı ile maternal bağlanma arasındaki ilişkinin incelenmesi amaçlandı. Yöntem: Tanımlayıcı ve ilişki arayıcı türde yapılan çalışmanın verileri, Ocak-Mart 2020 tarihleri arasında aile sağlığı merkezine başvuran doğum sonu dönemde 1-6 aylık bebeği olan 280 anneden toplandı. Veriler Kişisel bilgi formu, Maternal Bağlanma Ölçeği (MBÖ) ve Travmatik Doğum Algısı Ölçeği (TDAÖ) ile toplandı. Veriler ortanca, minimum-maksimum değerleri, Spearman korelasyon analizi ve Kruskal-Wallis analizi ile değerlendirildi. Bulgular: Çalışmamızda annelerin yaş ortancası 27 (17-41), yaşayan çocuk sayısı 2 (0-6)'dir. Annelerin \%80,7'si gebeliğini planladığını, \%97,1'inin gebelik takiplerini düzenli yaptırdığını, \%46,1'i doğumunu ebenin yaptırdığını belirtti. Annelerin \%71.8'i bebeklerini ilk 30 dakika içinde kucağına almış ve \%61.4'ü ilk emzirmeyi başlatmıştı. Annelerin MBÖ puan ortancası 104 (74-104), TDAÖ puan ortancası 69,5 (0-130)'dir. Çalıșmamızda annelerin MBÖ ve TDAÖ puan ortancaları arasında korelasyon analiz sonucuna göre anlamlı bir ilişki saptanmadı ( $\mathrm{r}=-0.031, \mathrm{p}=0.608)$. Annelerin TDAÖ'ne göre \%34.6'sının "orta" düzeyde travmatik doğum algısına sahip olduğu saptandı. Sonuç: Çalışmamızda annelerin maternal bağlanma düzeylerinin "yüksek", travmatik doğum algılarının "orta" düzeyde olduğu saptandı. Annelerin maternal bağlanma düzeyi ve travmatik doğum algıları arasında anlamlı ilişki yoktu. Buna göre gelecek çalışmalarda daha büyük örneklem grupları ile maternal bağlanma düzeyi ve travmatik doğum algısı incelenebilir.

Anahtar kelimeler: Doğum, travmatik doğum algısı, maternal bağlanma, ebelik.

Received / Geliş tarihi: 02.04.2021, Accepted / Kabul tarihi: 19.08.2021

${ }^{1}$ Master Student, Department of Midwifery of Health Sciences Institute, Selcuk University, KONYA (ORCID: 0000-0002-0408-5334)

${ }^{2}$ Assoc. Prof. Dr., Department of Midwifery of Health Sciences Faculty, Selcuk University, KONYA (ORCID: 0000-0001-9617-4897)

${ }^{3}$ Prof. Dr., Department of Family Medicine of Medicine Faculty, Selcuk University, Selcuklu/KONYA (ORCID: 0000-0001-6510-8010)

*Address for Correspondence / Yazışma Adresi: Department of Midwifery, Faculty of Health Sciences, Selcuk University, 42250, Selcuklu/KONYA-TÜRKIYE,

E-mail: alanhacer@selcuk.edu.tr

Calisir IN, Dikmen HA, Marakoglu K. An Investigation of the Relationship between Mothers' Traumatic Delivery Perception and Maternal Attachment. TJFMPC, 2021;15(4): 715-725.

DOI: $10.21763 /$ tjfmpc.908264 


\section{INTRODUCTION}

The most important reason why birth is a very special event is that it has psychological, physiological, and sociological aspects. Therefore, the mother should be evaluated in all aspects at birth. Birth is a milestone in the lives of both parents and the family. Every parent and family can perceive this process differently. This can be perceived as positive in some individuals and negative (i.e., traumatic) in others. ${ }^{1}$

Women's perceptions of the childbirth process are influenced by the women's personality traits, expectations, and the meaning she attributes to her birth experience, and it may be different for each woman. Callister investigated the perceptions of birth in mothers of different cultures and reported that women perceived birth positively as courage, an enlivening event, respect for the capacity to give birth, gaining experience, success, establishing a common bond with other mothers, and a spiritual experience that makes you feel closer to God. On the other hand, they also perceived it negatively as intense anxiety and fear. ${ }^{2}$

Traumatic birth is a woman's perception of "giving birth" as an injury or death threat for the baby or herself. ${ }^{3}$ The women's feelings are more important in women's perception of birth than the actual events experienced. Although labor is a natural process, it can be regarded by women as an unknown and fearful event. ${ }^{3,4}$ If the women's perception of traumatic birth is not evaluated and treated, it can damage family relationships, reduce breastfeeding, and, in the long term, cause emotional, cognitive, and behavioral disorders in their children. For this reason, it is important to prevent the traumatic birth experience in the protection and improvement of health. ${ }^{3}$

The effects of the perception of traumatic birth on women can be listed as disappointment about the birth, difficulty in family relationships, avoidance of sexual intercourse, fear of having a child again, guilty feeling that the baby has a negative experience, failure to establish a bond between mother and baby, and problems with breastfeeding. ${ }^{5}$ In this context, the perception of traumatic birth may also affect maternal attachment.

First days after birth are quite difficult for the mother who has to adapt to her newborn baby, deal with postpartum disorders, assume new roles, get accustomed to the new order in the family, and cope with the changes in her body. ${ }^{6}$ Maternal attachment is a unique love relationship that develops between the mother and the baby over time. $^{7}$ In the postpartum period, risk factors affecting maternal attachment are the mother's general poor relationship with her partner, not having social security, the baby's not distinguishing the mother from strangers, the baby's not having a health problem, support from the partner's family for child care, not getting enough social support, having an unwanted pregnancy, and living in a district/village for the longest time in life..$^{8,9}$

A mother's affectionate and sincere attachment to her baby, i.e., maternal attachment, is one of the most important factors that boost the child's healthy growth and development. The first attachment relationship that the baby experiences is the basis for the attachment relationships that it will experience later. ${ }^{10}$ The attachment style of the mother who gives the primary care in infancy is thought to affect romantic relationships, social relations, and healthy maintenance of social life during childhood, adolescence, adulthood, and old age. ${ }^{11}$ To this end, for the attachment relations to be healthy in the future life of the child, the motherbaby attachment should begin strongly in infancy. Therefore, maternal attachment is important.

Traumatic delivery may cause postpartum depression, posttraumatic stress, and delayed maternal attachment. ${ }^{12}$ There is no study in the literature examining the relationship between mothers' perception of traumatic birth and maternal attachment levels. For this reason, this study was carried out to better understand the perception of traumatic birth of mothers of 1 - to 6-month old babies and to determine the relationship between this perception and maternal attachment.

\section{Research Questions}

1. What is the maternal attachment level of the mothers?

2. What is the level of mothers' perception of traumatic birth?

3. Is there a relationship between mothers' maternal attachment level and their perception of traumatic birth?

\section{METHODS}

\section{Study Design}

The universe of this descriptive and correlational research was composed of mothers who were presented to nine family health centers in Konya city center between January and May 2020.

\section{Data Collection}

Although there are different rates in the literature, the prevalence of traumatic birth varies between $20 \%$ and $30 \%{ }^{3,13,14}$ The sample size of the study 
was calculated as 265 participants with the $\mathrm{G}^{*}$ Power program 3.1 with 0.20 (medium) effect size, statistical power of $90 \%$, and an $\alpha$ error probability level of $0.05 .{ }^{15}$ Considering a possible data loss, we planned to take $10 \%$ more. During the data collection period, 293 women were interviewed, but 280 people agreed to participate in the study, so the study was completed with 280 women.

\section{Data Collection Tools}

The data were collected using the "Personal Information Form" containing personal information; the Maternal Attachment Scale (MAS) to evaluate the mother-infant attachment, and the Traumatic Birth Perception Scale (TBPS) to evaluate the perception of traumatic birth. Mothers who met the inclusion criteria were informed about the study and asked whether they agreed to participate in the study. Verbal consent was obtained from mothers who agreed to participate in the study. It took 15-20 minutes to fill out the forms. Study data were collected in privacy in a special room allocated in family health centers. Care was taken to ensure that the room where the data were collected was warm and bright, and nobody was allowed to enter this room other than the participant and the researcher.

\section{Personal Information Form}

We developed the Personal Information Form in line with the literature..$^{8,10,12,13,16}$ The form consists of 38 items in total: 12 items examining sociodemographic characteristics (age, marital status, family type, marriage age, educational status, spouse's educational status, profession, income status); 14 items examining obstetric characteristics (the number of pregnancies, the number of living/dead children and abortus, last birth experience, last pregnancy outcome, the method for the preparation for delivery, method of delivery, education status, source of information); and, 12 items examining the characteristics of the mother and the baby after birth.

\section{Maternal Attachment Scale (MAS)}

The MAS was developed by Mary E. Muller (1994) to measure attachment by maternal affection. The content validity of the scale was evaluated by linguists, theorists, obstetrics nurses, pediatric nurses, and 12 experts with a newborn. ${ }^{17}$ Since the MAS is a self-administered scale, it can be administered only to individuals who are literate and can understand what they read. The scale consists of twenty-six 4-point Likert-type items. Each item includes direct statements, and is scored as: Always (a) $=4$ points, Often (b) $=3$ points, Sometimes $(\mathrm{c})=2$ points, and Never $(\mathrm{d})=1$ point.
A general score is obtained from the sum of all items. Higher scores indicate higher maternal attachment. The score range of the scale varies between 26 and 104. The scale does not have a cutoff score. The MAS is administered to mothers with at least a 1-month-old baby. It is not applied to pregnant women and those with a baby younger than 1 month. ${ }^{10}$ Permission was obtained to use the scale in this study. The Cronbach alpha coefficient in this study was calculated as 0.89 .

\section{Traumatic Birth Perception Scale (TBPS)}

The TBPS is a measurement tool developed by Yalniz et al. (2016) to determine the level of women's perception of labor as traumatic. This scale is applied in the following periods to identify the women who perceive labor as traumatic: at $15^{\text {th }}$ $49^{\text {th }}$ day follow-ups, in the preconception period, during prenatal and postpartum follow-ups, or in delivery rooms and obstetric wards. ${ }^{3}$ Based on the internal consistency analysis, the Cronbach alpha reliability coefficient of the scale was found as 0.89 . The scale consists of 13 items and the minimum score of the scale is 0 and the maximum score is 130 . Each item has a scoring system from 0 to 10: 0 -26 very low, 27-52 low, 53-78 medium, 79-104 high, 105-130 very high traumatic birth perception level. ${ }^{3}$ Permission was obtained to use the scale in this study. In this study, the Cronbach alpha coefficient was calculated as 0.90 .

\section{Ethical Permission}

Before the study, ethical permission was obtained from Konya Selcuk University Faculty of Health Sciences Non-Invasive Clinical Research Ethics Committee (2019/14544). Institutional permission for the study was obtained from Konya Provincial Health Directorate (2019/86737044). The permissions to use all the scales in the study were obtained from the researchers who have established the scales' Turkish validity and reliability. The women participating in the study were informed that their personal information would be kept confidential, and then, their verbal consents were obtained.

\section{Data Analysis}

SPSS 20.0 was used for statistical analyses of the data. Before the analyses, we checked whether the data was normally distributed or not, and found by the Kolmogorov Smirnov test that the data were not normally distributed. In the analyses, together with descriptive statistics, the Mann-Whitney U test was used to compare two independent groups, the Kruskal Wallis test to compare more than two independent groups, and the Spearman correlation 
analysis to compare two quantitative variables. Statistical significance was set at $\mathrm{p}<0.05$. $^{18}$

\section{RESULTS}

We observed that the median age of the mothers was 27 years (17-41), and the median total number of pregnancies was $2(1-8)$. We also observed that $47.9 \%$ of the mothers were secondary education graduates, $81.8 \%$ were unemployed, $15 \%$ of them had 'insufficient' perceived income, and $79.3 \%$ lived in a city for the longest time in their life. We found that $61.1 \%$ of the mothers had vaginal delivery in the last childbirth, $80.7 \%$ had a planned pregnancy, $46.1 \%$ of them were attended by a midwife during delivery, and $65.4 \%$ of them received information about the labor during their pregnancy (Table 1).

The mothers' median MAS score was 104 (74-104). Their median TBPS score was 69.5 (0130). Categorical distribution of the mothers' TBPS scores was: $9.3 \%$ very low, $19.6 \%$ low, $34.6 \%$ medium, $24.6 \%$ high, and $11.8 \%$ very high traumatic birth perception.
In the last childbirth experience, $60 \%$ of the mothers stated that the support of the attending midwife/physician and $53.2 \%$ stated that the violation of privacy was at the "expected level"; and $36.4 \%$ stated fear, $37.9 \%$ anxiety, $36.1 \%$ pain, and $22.1 \%$ postpartum pain was "more than expected" (Table 2).

The median birth weight of the babies in the study was 3207.5 (900-4500) grams and their then-current median weight was 5400 (2000-11570) grams. Infants were on median 3 (1-24) months, $46.4 \%$ of babies were girls, $98.6 \%$ of the babies were born in the sex the mothers wanted, $28.2 \%$ of them took their babies in their arms for the first time at post-partum 31 st minute or later, and $38.6 \%$ of them breastfed them for the first time after the 31 st minute after delivery. We found that $82.1 \%$ of the babies were able to distinguish their mothers from strangers, $85.4 \%$ did not stay in an incubator, $85.4 \%$ did not develop any health problems after birth, and $78.2 \%$ of the mothers fed their babies with breastfeeding (Table 3 ).

Table 1. Mothers' socio-demographic and obstetric characteristics $(n=280)$

\begin{tabular}{|l|c|}
\hline Variables & $\begin{array}{c}\text { Median } \\
\text { (Minimum-Maximum) }\end{array}$ \\
\hline Mother's age & $27(17-41)$ \\
\hline Duration of marriage (Year) & $5(1-22)$ \\
\hline Number of pregnancies & $2(1-8)$ \\
\hline Number of living children & $2(0-6)$ \\
\hline \multicolumn{2}{|c|}{$\mathbf{n ( \% )}$} \\
\hline Family Type & $231(82.5)$ \\
\hline Nucleus & $49(17.5)$ \\
Extended & $68(24.2)$ \\
\hline Education Status & $134(47.9)$ \\
\hline Primary School & $78(27.9)$ \\
Secondary School & $51(18.2)$ \\
University or higher & $229(81.8)$ \\
\hline Employment Status & $42(15)$ \\
\hline Employed & $218(77.9)$ \\
Unemployed & $20(7.1)$ \\
\hline Perception of Income Level & $222(79.3)$ \\
\hline Income more than expenses & $58(20.7)$ \\
Income equals expenses & $171(61)$ \\
Expenses more than income & $15(5.4)$ \\
\hline Place of residence resided in longest & $37(13.2)$ \\
\hline City & $57(20.4)$ \\
District & \\
\hline Mode of last delivery & \\
\hline Vaginal & \\
Vaginal with intervention & Cesarean section with general anesthesia Cesarean section \\
with epidural-spinal anesthesia & \\
\hline Planned pregnancy & \\
\hline
\end{tabular}




\begin{tabular}{|l|c|}
\hline Yes & $226(80.7)$ \\
No & $54(19.3)$ \\
\hline Perinatal follow-up & $272(97.1)$ \\
\hline Yes & $8(2.9)$ \\
No & $151(53.9)$ \\
\hline Who assisted the birth & $129(46.1)$ \\
\hline Physician & $183(65.4)$ \\
Midwife & $97(34.6)$ \\
\hline Information received during pregnancy \\
\hline Yes & $217(77.5)$ \\
No & $41(14.6)$ \\
\hline If yes, who provided the information & $22(7.9)$ \\
\hline Health care professionals \\
Family & $157(56.1)$ \\
Media & $12(4.3)$ \\
\hline Information was sufficient & $111(39.6)$ \\
\hline Yes & \\
No & \\
Partially & \\
\hline
\end{tabular}

Table 2. Mothers' characteristics regarding their last childbirth experience $(n=280)$

\begin{tabular}{|l|c|}
\hline Variables & $n \mathbf{( \% )}$ \\
\hline Midwife support & $18(6.4)$ \\
\hline Less than expected & $168(60)$ \\
At an expected level & $94(33.6)$ \\
More than expected & $37(13.2)$ \\
\hline Physician support & $168(60)$ \\
\hline Less than expected & $75(26.8)$ \\
At an expected level & $50(17.9)$ \\
More than expected & $128(45.7)$ \\
\hline Fear & $102(36.4)$ \\
\hline Less than expected & $51(18.2)$ \\
At an expected level & $123(43.9)$ \\
More than expected & $106(37.9)$ \\
\hline Anxiety & $42(15)$ \\
\hline Less than expected & $137(48.9)$ \\
At an expected level & $101(36.1)$ \\
More than expected & $64(22.9)$ \\
\hline Pain & $154(55)$ \\
\hline Less than expected & $62(22.1)$ \\
At an expected level & $91(32.5)$ \\
More than expected & $149(53.2)$ \\
\hline Post-partum pain & $40(14.3)$ \\
\hline Less than expected & \\
At an expected level & \\
More than expected & \\
\hline Violation of privacy & Less than expected \\
At an expected level & \\
More than expected &
\end{tabular}


Table 3. Features related to mother-infant relationship in the postnatal period $(n=280)$

\begin{tabular}{|c|c|}
\hline Variables & $\begin{array}{c}\text { Median } \\
\text { (Minimum-Maximum) }\end{array}$ \\
\hline Babies' weight at birth (gr) & $3207.50(900-4500)$ \\
\hline Babies' then-current birth (gr) & $5400(2000-11570)$ \\
\hline \multirow[t]{2}{*}{ Babies age (month) } & $3(1-24)$ \\
\hline & $n(\%)$ \\
\hline \multicolumn{2}{|l|}{ Gender } \\
\hline Female & $130(46.4)$ \\
\hline Male & $150(53.6)$ \\
\hline \multicolumn{2}{|c|}{ Satisfaction with the baby's gender } \\
\hline Yes & $276(98.6)$ \\
\hline No & $4(1.4)$ \\
\hline \multicolumn{2}{|l|}{ Holding the baby for the first time } \\
\hline Within postpartum 30 minutes & $201(71.8)$ \\
\hline After postpartum 30 minutes & $79(28.2)$ \\
\hline \multicolumn{2}{|l|}{ First breastfeeding } \\
\hline Within postpartum 30 minutes & $172(61.4)$ \\
\hline After postpartum 30 minutes & $108(38.6)$ \\
\hline \multicolumn{2}{|l|}{ Mode of feeding the baby } \\
\hline Breastfeeding & $219(78.2)$ \\
\hline Formula/supplements & $15(5.4)$ \\
\hline Breastfeeding + formula & $46(16.4)$ \\
\hline \multicolumn{2}{|c|}{ Status of baby's recognition of the mother } \\
\hline Yes & $230(82.1)$ \\
\hline No & $50(17.9)$ \\
\hline \multicolumn{2}{|c|}{ Status of husband's wanting the baby } \\
\hline Yes & $268(95.7)$ \\
\hline No & $12(4.3)$ \\
\hline \multicolumn{2}{|l|}{ Baby stayed in an incubator } \\
\hline Yes & $41(14.6)$ \\
\hline No & $239(85.4)$ \\
\hline \multicolumn{2}{|l|}{ Baby has a health problem } \\
\hline Yes & $41(14.6)$ \\
\hline No & $239(85.4)$ \\
\hline
\end{tabular}

There was no statistically significant relationship between the median MAS score of the mothers and mothers' age, duration of the marriage, the total number of living children, birth weights and then-current weights of the babies, and the age of the babies $(p \geq 0.05)$. A very weak, positive, and statistically significant relationship was found between the maternal attachment level of the mothers and the total number of births ( $\mathrm{rs}=0.11$; $\mathrm{p}<0.05$ ). A statistically insignificant relationship was found between the level of traumatic birth perception of the mothers and maternal age, duration of the marriage, total number of births, total number of living children, babies' birth weights, and their then-current weights $(p \geq 0.05)$. There was no statistically significant relationship between maternal attachment level and traumatic birth perception levels of the mothers $(\mathrm{p} \geq 0.05)$ (Table 4).
As seen in Table 5 in which maternal attachment and traumatic birth perception levels and socio-demographic and obstetric characteristics are compared, only a statistically significant difference was found between mothers' perception of income status and the MAS score $(p=0.041)$. There was no statistically significant difference between other variables and the mother's MAS and TBPS scores ( $\mathrm{p} \geq 0.05$ ) (Table 5).

There was a statistically significant difference between the baby's ability to distinguish its mother from strangers and the median MAS score $(p=0.048)$. There was a statistically significant difference between the mothers' experience of fear, anxiety, pain, and postpartum pain and the median TBPS score $(\mathrm{p}<0.001)$ (Table 6). 
Table 4. Evaluation of mothers' some socio-demographic, obstetric, and the number of children and TBPS and MAS scores by correlation analysis $(n=280)$

\begin{tabular}{|l|l|l|l|l|}
\hline Variables & \multicolumn{2}{|c|}{ MAS } & \multicolumn{2}{c|}{ TBPS } \\
\hline Mother's age & $\boldsymbol{r}_{\boldsymbol{s}}$ & $\boldsymbol{p}$ & $\boldsymbol{r}_{\boldsymbol{s}}$ & $\boldsymbol{p}$ \\
\hline Duration of marriage & 0.010 & 0.865 & -0.109 & 0.068 \\
\hline Total number of births & 0.048 & 0.422 & 0.008 & 0.900 \\
\hline Total number of living children & 0.119 & $\mathbf{0 . 0 4 7}$ & 0.017 & 0.780 \\
\hline Baby's birth weight & 0.088 & 0.142 & 0.028 & 0.641 \\
\hline Baby's then-current weight & -0.039 & 0.519 & -0.070 & 0.242 \\
\hline Baby's age & 0.002 & 0.974 & 0.007 & 0.912 \\
\hline TBPS & 0.029 & 0.632 & 0.019 & 0.754 \\
\hline
\end{tabular}

$\mathrm{r}_{\mathrm{s}}$ : Spearman's correlation coefficient, MAS: Maternal Attachment Scale, TBPS: Traumatic Birth Perception Scale.

Table 5. Comparison of maternal attachment and traumatic birth perception levels and sociodemographic and obstetric characteristics of mothers $(n=280)$

\begin{tabular}{|c|c|c|c|c|c|}
\hline Variables & $n$ & $\begin{array}{l}\text { MAS } \\
\text { Median } \\
\text { (Minimum- } \\
\text { Maximum) }\end{array}$ & $z, K W ; p$ & $\begin{array}{l}\text { TBPS } \\
\text { Median } \\
\text { (Minimum- } \\
\text { Maximum) }\end{array}$ & $z, K W ; p$ \\
\hline \multicolumn{6}{|l|}{ Family Type } \\
\hline $\begin{array}{l}\text { Nucleus } \\
\text { Extended }\end{array}$ & $\begin{array}{l}231 \\
49\end{array}$ & $\begin{array}{l}103(74-104) \\
104(81-104)\end{array}$ & $\begin{array}{l}z=-0.600 \\
p=0.548\end{array}$ & $\begin{array}{l}70(0-130) \\
69(4-124)\end{array}$ & $\begin{array}{l}z=-0.560 \\
p=0.575\end{array}$ \\
\hline \multicolumn{6}{|l|}{ Education Status } \\
\hline $\begin{array}{l}\text { Primary } \\
\text { Secondary } \\
\text { University and higher }\end{array}$ & $\begin{array}{l}68 \\
134 \\
78 \\
\end{array}$ & $\begin{array}{l}104(78-104) \\
104(80-104) \\
103(74-104) \\
\end{array}$ & $\begin{array}{l}K W=5.053 \\
p=0.080\end{array}$ & $\begin{array}{l}73.5(7-124) \\
69(4-130) \\
68.5(0-130) \\
\end{array}$ & $\begin{array}{l}K W=1.791 \\
p=0.408\end{array}$ \\
\hline \multicolumn{6}{|l|}{ Employment Status } \\
\hline $\begin{array}{l}\text { Employed } \\
\text { Unemployed }\end{array}$ & $\begin{array}{l}51 \\
229\end{array}$ & $\begin{array}{l}103(74-104) \\
104(78-104)\end{array}$ & $\begin{array}{l}z=-1.346 \\
p=0.178\end{array}$ & $\begin{array}{l}67(0-124) \\
70(4-130)\end{array}$ & $\begin{array}{l}z=-1.928 \\
p=0.054\end{array}$ \\
\hline \multicolumn{6}{|l|}{ Perception of Income } \\
\hline $\begin{array}{l}\text { Income less than expenses } \\
\text { Income equals expenses } \\
\text { Income more than expenses }{ }^{\text {a }}\end{array}$ & $\begin{array}{l}42 \\
218 \\
20\end{array}$ & $\begin{array}{l}104(78-104) \\
103(74-104) \\
101.5(91-104) \\
\end{array}$ & $\begin{array}{l}K W=6.369 \\
\boldsymbol{p}=\mathbf{0 . 0 4 1}\end{array}$ & $\begin{array}{l}74(7-124) \\
69(4-130) \\
70(0-124) \\
\end{array}$ & $\begin{array}{l}K W=0.837 \\
p=0.658\end{array}$ \\
\hline \multicolumn{6}{|l|}{ Place resided longest } \\
\hline $\begin{array}{l}\text { Province } \\
\text { District }\end{array}$ & $\begin{array}{l}222 \\
58\end{array}$ & $\begin{array}{l}104(74-104) \\
104(78-104)\end{array}$ & $\begin{array}{l}z=-1.356 \\
p=0.175\end{array}$ & $\begin{array}{l}69(0-130) \\
74(17-120)\end{array}$ & $\begin{array}{l}z=-0.816 \\
p=0.415\end{array}$ \\
\hline \multicolumn{6}{|l|}{ Mode of last delivery } \\
\hline $\begin{array}{l}\text { Vaginal } \\
\text { Vaginal with intervention } \\
\text { Cesarean section with general } \\
\text { anesthesia } \\
\text { Cesarean section with epidural- } \\
\text { spinal anesthesia }\end{array}$ & $\begin{array}{l}171 \\
15 \\
37 \\
\\
57\end{array}$ & $\begin{array}{l}104(78-104) \\
102(85-104) \\
103(91-104) \\
104(74-104)\end{array}$ & $\begin{array}{l}K W=3.005 \\
p=0.391\end{array}$ & $\begin{array}{l}69(0-130) \\
78(35-111) \\
74(22-124) \\
68(11-130)\end{array}$ & $\begin{array}{l}K W=3.196 \\
p=0.362\end{array}$ \\
\hline \multicolumn{6}{|l|}{ Planned pregnancy } \\
\hline $\begin{array}{l}\text { Yes } \\
\text { No }\end{array}$ & $\begin{array}{l}226 \\
54\end{array}$ & $\begin{array}{l}103(74-104) \\
104(78-104)\end{array}$ & $\begin{array}{l}z=-0.260 \\
p=0.795\end{array}$ & $\begin{array}{l}68.5(0-130) \\
77.5(7-130)\end{array}$ & $\begin{array}{l}z=-1.660 \\
p=0.097\end{array}$ \\
\hline \multicolumn{6}{|l|}{ Pregnancy follow-up } \\
\hline $\begin{array}{l}\text { Yes } \\
\text { No }\end{array}$ & $\begin{array}{l}272 \\
8 \\
\end{array}$ & $\begin{array}{l}104(74-104) \\
103.5(91-104) \\
\end{array}$ & $\begin{array}{l}z=-0.021 \\
p=0.983\end{array}$ & $\begin{array}{l}69.5(0-130) \\
66.5(7-103)\end{array}$ & $\begin{array}{l}z=-0.585 \\
p=0.559\end{array}$ \\
\hline \multicolumn{6}{|l|}{ Person assisted delivery } \\
\hline $\begin{array}{l}\text { Physician } \\
\text { Midwife }\end{array}$ & $\begin{array}{l}151 \\
129\end{array}$ & $\begin{array}{l}103(74-104) \\
104878-104)\end{array}$ & $\begin{array}{l}z=-1.828 \\
p=0.067\end{array}$ & $\begin{array}{l}68(0-130) \\
70(4-130) \\
\end{array}$ & $\begin{array}{l}z=-0.776 \\
p=0.438\end{array}$ \\
\hline
\end{tabular}




\begin{tabular}{|c|c|c|c|c|c|}
\hline \multicolumn{6}{|c|}{ Received information during pregnancy } \\
\hline $\begin{array}{l}\text { Yes } \\
\text { No }\end{array}$ & $\begin{array}{l}183 \\
97\end{array}$ & $\begin{array}{l}103(74-104) \\
104(81-104)\end{array}$ & $\begin{array}{l}z=-1.504 \\
p=0.133\end{array}$ & $\begin{array}{l}70(0-130) \\
68(7-124)\end{array}$ & $\begin{array}{l}z=-0.634 \\
p=0.526\end{array}$ \\
\hline \multicolumn{6}{|c|}{ If yes, where did you get information } \\
\hline $\begin{array}{l}\text { Health care professional } \\
\text { Family } \\
\text { Media }\end{array}$ & $\begin{array}{l}217 \\
41 \\
22 \\
\end{array}$ & $\begin{array}{l}104(74-104) \\
103(78-104) \\
102.5(92-104) \\
\end{array}$ & $\begin{array}{l}K W=3.770 \\
p=0.152\end{array}$ & $\begin{array}{l}68(0-130) \\
77(30-120) \\
78.5(10-119) \\
\end{array}$ & $\begin{array}{l}K W=3.727 \\
p=0.155\end{array}$ \\
\hline \multicolumn{6}{|l|}{ Information was sufficient } \\
\hline $\begin{array}{l}\text { Yes } \\
\text { No } \\
\text { Partially }\end{array}$ & $\begin{array}{l}157 \\
12 \\
111\end{array}$ & $\begin{array}{l}103(80-104) \\
103(93-104) \\
104(74-104)\end{array}$ & $\begin{array}{l}K W=2.185 \\
p=0.335\end{array}$ & $\begin{array}{l}68(0-130) \\
75.5(17-120) \\
70(7-125)\end{array}$ & $\begin{array}{l}K W=1.035 \\
p=0.596\end{array}$ \\
\hline
\end{tabular}

z: Mann Whitney U test, KW: Kruskal Wallis H test, MAS: Maternal Attachment Scale, TBPS: Traumatic Birth

Perception Scale. ${ }^{\text {a }}$ group whose significance was established by the Bonferroni test.

Table 6. Comparison of the maternal attachment and traumatic birth perception levels of the mothers with the birth experience and mother-infant relationship characteristics $(n=\mathbf{2 8 0})$

\begin{tabular}{|c|c|c|c|c|c|}
\hline Variables & $n$ & $\begin{array}{l}\text { MAS } \\
\text { Median } \\
\text { (Minimum- } \\
\text { Maximum) }\end{array}$ & $z, K W ; p$ & $\begin{array}{l}\text { TBPS } \\
\text { Median } \\
\text { (Minimum- } \\
\text { Maximum) }\end{array}$ & $z, K W ; p$ \\
\hline \multicolumn{6}{|l|}{ Midwife support } \\
\hline $\begin{array}{l}\text { Less than expected } \\
\text { As expected } \\
\text { More than expected }\end{array}$ & $\begin{array}{l}18 \\
168 \\
94\end{array}$ & $\begin{array}{l}103(84-104) \\
103(74-104) \\
104(81-104)\end{array}$ & $\begin{array}{l}K W=5.961 \\
p=0.051\end{array}$ & $\begin{array}{l}61.5(20-117) \\
71(7-130) \\
67(0-130)\end{array}$ & $\begin{array}{l}K W=1.006 \\
p=0.605\end{array}$ \\
\hline \multicolumn{6}{|l|}{ Physician support } \\
\hline $\begin{array}{l}\text { Less than expected } \\
\text { As expected } \\
\text { More than expected }\end{array}$ & $\begin{array}{l}37 \\
168 \\
75 \\
\end{array}$ & $\begin{array}{l}104(74-104) \\
103(80-104) \\
104(81-104)\end{array}$ & $\begin{array}{l}K W=0.561 \\
p=0.756\end{array}$ & $\begin{array}{l}77(18-120) \\
70(7-130) \\
64(0-130)\end{array}$ & $\begin{array}{l}K W=1.787 \\
p=0.409\end{array}$ \\
\hline \multicolumn{6}{|l|}{ Fear } \\
\hline $\begin{array}{l}\text { Less than expected } \\
\text { As expected } \\
\text { More than expected }{ }^{\text {a }}\end{array}$ & $\begin{array}{l}50 \\
128 \\
102 \\
\end{array}$ & $\begin{array}{l}102(91-104) \\
104(78-104) \\
104(74-104)\end{array}$ & $\begin{array}{l}K W=6.004 \\
p=0.050\end{array}$ & $\begin{array}{l}40(0-120) \\
69(7-122) \\
80.5(19-130) \\
\end{array}$ & $\begin{array}{l}K W=27.86 \\
\boldsymbol{p}=\mathbf{0 . 0 0 0}\end{array}$ \\
\hline \multicolumn{6}{|l|}{ Anxiety } \\
\hline $\begin{array}{l}\text { Less than expected } \\
\text { As expected } \\
\text { More than expected }\end{array}$ & $\begin{array}{l}51 \\
123 \\
106 \\
\end{array}$ & $\begin{array}{l}102(91-104) \\
104(78-104) \\
104(74-104)\end{array}$ & $\begin{array}{l}K W=5.095 \\
p=0.078\end{array}$ & $\begin{array}{l}55(0-124) \\
67(7-122) \\
79(19-130) \\
\end{array}$ & $\begin{array}{l}K W=20.99 \\
\boldsymbol{p}=\mathbf{0 . 0 0 0}\end{array}$ \\
\hline \multicolumn{6}{|l|}{ Pain } \\
\hline $\begin{array}{l}\text { Less than expected } \\
\text { As expected } \\
\text { More than expected }\end{array}$ & $\begin{array}{l}42 \\
137 \\
101 \\
\end{array}$ & $\begin{array}{l}103(81-104) \\
104(74-104) \\
103(80-104) \\
\end{array}$ & $\begin{array}{l}K W=0.173 \\
p=0.917\end{array}$ & $\begin{array}{l}62.5(10-120) \\
67(0-124) \\
78(20-130) \\
\end{array}$ & $\begin{array}{l}K W=15.26 \\
\boldsymbol{p}=\mathbf{0 . 0 0 0}\end{array}$ \\
\hline \multicolumn{6}{|l|}{ Postpartum pain } \\
\hline $\begin{array}{l}\text { Less than expected } \\
\text { As expected } \\
\text { More than expected }{ }^{\text {a }}\end{array}$ & $\begin{array}{l}64 \\
154 \\
62 \\
\end{array}$ & $\begin{array}{l}103(78-104) \\
103.5(74-104) \\
104(80-104) \\
\end{array}$ & $\begin{array}{l}K W=0.246 \\
p=0.884\end{array}$ & $\begin{array}{l}57.5(0-122) \\
69.5(4-130) \\
88.5(21-130) \\
\end{array}$ & $\begin{array}{l}K W=18.82 \\
\boldsymbol{p}=\mathbf{0 . 0 0 0}\end{array}$ \\
\hline \multicolumn{6}{|l|}{ Violation of privacy } \\
\hline $\begin{array}{l}\text { Less than expected } \\
\text { As expected } \\
\text { More than expected }\end{array}$ & $\begin{array}{l}91 \\
149 \\
40 \\
\end{array}$ & $\begin{array}{l}103(74-104) \\
104(78-104) \\
104(81-104)\end{array}$ & $\begin{array}{l}K W=\mathbf{5 . 9 8 1} \\
p=\mathbf{0 . 0 5 0}\end{array}$ & $\begin{array}{l}70(0-130) \\
70(7-130) \\
64(4-124)\end{array}$ & $\begin{array}{l}K W=0.097 \\
p=0.952\end{array}$ \\
\hline \multicolumn{6}{|l|}{ Baby's gender } \\
\hline $\begin{array}{l}\text { Female } \\
\text { Male }\end{array}$ & $\begin{array}{l}130 \\
150\end{array}$ & $\begin{array}{l}104(84-104) \\
103(74-104)\end{array}$ & $\begin{array}{l}z=-1.224 \\
p=0.221\end{array}$ & $\begin{array}{l}67.5(0-130) \\
71(4-124)\end{array}$ & $\begin{array}{l}z=-1.610 \\
p=0.108\end{array}$ \\
\hline
\end{tabular}




\begin{tabular}{|c|c|c|c|c|c|}
\hline $\begin{array}{l}\text { Yes } \\
\text { No }\end{array}$ & $\begin{array}{l}276 \\
4\end{array}$ & $\begin{array}{l}104(74-104) \\
103(98-104)\end{array}$ & $\begin{array}{l}z=-0.117 \\
p=0.907\end{array}$ & $\begin{array}{l}69(0-130) \\
89.5(58-114)\end{array}$ & $\begin{array}{l}z=-1.359 \\
p=0.176\end{array}$ \\
\hline \multicolumn{6}{|c|}{ Holding the baby for the first time } \\
\hline 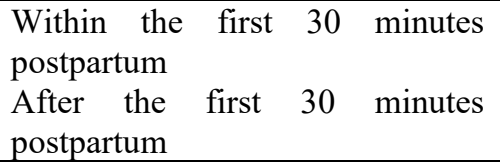 & $\begin{array}{l}201 \\
79\end{array}$ & $\begin{array}{l}103(80-104) \\
104(74-104)\end{array}$ & $\begin{array}{l}z=-0.789 \\
p=0.430\end{array}$ & $\begin{array}{l}70(0-130) \\
69(11-130)\end{array}$ & $\begin{array}{l}z=-0.127 \\
p=0.899\end{array}$ \\
\hline \multicolumn{6}{|l|}{ First breastfeeding time } \\
\hline $\begin{array}{l}\text { Within the first } 30 \text { minutes } \\
\text { postpartum } \\
\text { After the first } 30 \\
\text { postpartum }\end{array}$ & $\begin{array}{l}172 \\
108\end{array}$ & $\begin{array}{l}103.5(80-104) \\
104(74-104)\end{array}$ & $\begin{array}{l}z=-0.163 \\
p=0.871\end{array}$ & $\begin{array}{l}68(0-130) \\
70(4-130)\end{array}$ & $\begin{array}{l}z=-1.446 \\
p=0.148\end{array}$ \\
\hline \multicolumn{6}{|l|}{ Mode of feeding the baby } \\
\hline $\begin{array}{l}\text { Breastfeeding } \\
\text { Formula/supplement } \\
\text { Breastfeeding + formula }\end{array}$ & $\begin{array}{l}219 \\
15 \\
46 \\
\end{array}$ & $\begin{array}{l}104(78-104) \\
102(74-104) \\
104(91-104) \\
\end{array}$ & $\begin{array}{l}K W=2.768 \\
p=0.251\end{array}$ & $\begin{array}{l}69(0-130) \\
77(48-124) \\
72.5(7-130) \\
\end{array}$ & $\begin{array}{l}K W=1.285 \\
p=0.526\end{array}$ \\
\hline \multicolumn{6}{|c|}{ Baby's ability to recognize the mother } \\
\hline $\begin{array}{l}\text { Yes } \\
\text { No }\end{array}$ & $\begin{array}{l}230 \\
50\end{array}$ & $\begin{array}{l}103(74-104) \\
104(80-104)\end{array}$ & $\begin{array}{l}z=-1.981 \\
p=\mathbf{0 . 0 4 8}\end{array}$ & $\begin{array}{l}70(0-130) \\
68(17-124)\end{array}$ & $\begin{array}{l}z=-0.515 \\
p=0.607\end{array}$ \\
\hline \multicolumn{6}{|c|}{ Husband's status of wanting the baby } \\
\hline $\begin{array}{l}\text { Yes } \\
\text { No }\end{array}$ & $\begin{array}{l}268 \\
12\end{array}$ & $\begin{array}{l}103.5(74-104) \\
104(78-104)\end{array}$ & $\begin{array}{l}z=-0.258 \\
p=0.796\end{array}$ & $\begin{array}{l}69(0-130) \\
87.5(40-115)\end{array}$ & $\begin{array}{l}z=-1.403 \\
p=0.161\end{array}$ \\
\hline \multicolumn{6}{|l|}{ Baby stayed in an incubator } \\
\hline $\begin{array}{l}\text { Yes } \\
\text { No }\end{array}$ & $\begin{array}{l}41 \\
239 \\
\end{array}$ & $\begin{array}{l}104(81-104) \\
104(74-104)\end{array}$ & $\begin{array}{l}z=-0.449 \\
p=0.653\end{array}$ & $\begin{array}{l}63(7-130) \\
70(0-130)\end{array}$ & $\begin{array}{l}z=-1.184 \\
p=0.854\end{array}$ \\
\hline \multicolumn{6}{|l|}{ Baby health problems } \\
\hline $\begin{array}{l}\text { Yes } \\
\text { No }\end{array}$ & $\begin{array}{l}41 \\
239\end{array}$ & $\begin{array}{l}104(74-104) \\
103(78-104)\end{array}$ & $\begin{array}{l}z=-1.007 \\
p=0.314\end{array}$ & $\begin{array}{l}63(7-121) \\
70(0-130)\end{array}$ & $\begin{array}{l}z=-0.798 \\
p=0.425\end{array}$ \\
\hline
\end{tabular}

z: Mann Whitney U test, KW: Kruskal Wallis H test, MAS: Maternal Attachment Scale, TBPS: Traumatic Birth

Perception Scale. ${ }^{a}$ Group whose significance was established by the Bonferroni test.

\section{DISCUSSION}

In the present study, we found that, in the last childbirth experience, $60 \%$ of the mothers stated that the support of the attending midwife/physician and $53.2 \%$ stated that the violation of privacy was at the "expected level"; and $36.4 \%$ stated fear, $37.9 \%$ anxiety, $36.1 \%$ pain, and $22.1 \%$ postpartum pain was "more than expected" (Table 2). Similar to our results, Bay (2019) found that $56.4 \%$ of the mothers stated that the midwife support in the last labor and $46.7 \%$ stated that the violation of privacy was at the "expected level", and 30.9\% stated that fear, $31.1 \%$. anxiety, $31.8 \%$ pain, and $27.5 \%$ postpartum pain was "more than expected". ${ }^{16}$ Accordingly, it can be deduced that "respect for privacy" and "midwife and physician support" were not sufficient during childbirth, and fear of birth, anxiety and pain were moderate. Midwives and physicians should support more expectant mothers psychologically and physically and be more sensitive about privacy during the labor process. In addition, expectant mothers should be allowed to express their fears and concerns about labor. Nonpharmacological practices such as breathing, massage, position change, and movement, especially from the latent phase, should be taught to expectant mothers to increase their comfort during the labor process and to reduce their pain.

The maternal attachment level of the mothers was "high" (101.51 \pm 4.69) (Table 4). This finding answers our first research question. Kavlak and Sirin (2009) reported that the mean MAS score of the mothers with a 1-month-old baby was 94.87 \pm 6.04 , and the mean MAS score of the mothers with a 4-month-old baby was $95.85 \pm 6.29 .{ }^{10}$ Alan and Ege (2013) found the mean MAS score of the mothers as $96.53 \pm 9.25 .{ }^{8}$ In our study, mothers' maternal attachment levels were higher than the literature. The difference can be related to the number of samples. The sample size in our study was higher than those of the other two studies, and the levels of maternal attachment may have changed as more mothers were reached. In our study, no statistically significant relationship was found between maternal attachment level and maternal age, duration of the marriage, number of living children, babies' birth weight and thencurrent weights, and babies' age $(\mathrm{p} \geq 0.05)$. Similar 
to our study, Kavlak and Şirin (2009) found that maternal attachment level was not correlated with maternal age and duration of the marriage. ${ }^{10}$ Alan and Ege (2013) found a very weak, negative, and statistically insignificant relationship between maternal age and the duration of the marriage. ${ }^{8}$ With new studies, the factors affecting mothers' maternal attachment levels need to be identified.

We found that maternal attachment levels increased as the number of births increased (Table 4). Şen (2007) found that maternal attachment weakens as the number of children increases, and maternal attachment gets stronger as the duration of the birth interval increases. ${ }^{19}$ On the other hand, Alan and Ege (2013) found that as the number of births and children increased, maternal attachment level decreased. ${ }^{8}$ Unlike the literature, our study shows that there is a positive relationship between the number of births and maternal attachment. It is thought that this outcome is related to the majority of the pregnancies that were wanted by mothers $(80.7 \%)$ and their spouses $(95.7 \%)$ in our study.

Traumatic birth perception of the mothers in the present study was at a medium level $(69.10 \pm$ 28.31). This finding answers our second research question. Similar to our study, Bay (2019) found mothers' perception of traumatic birth at a medium level. ${ }^{16}$ Şahin (2020) also found the traumatic birth perception of expectant mothers at a medium level. ${ }^{20}$ According to the results of studies conducted in different provinces of Turkey, we can say that the traumatic birth perception of mothers in Turkish society is at a medium level.

There was no statistically significant relationship between the maternal attachment levels of the mothers and their perception of traumatic birth ( $p \geq 0.05)$ (Table 4). This finding answers our third research question. The reason why there was no relationship between the maternal attachment levels of the mothers and the perception of traumatic birth may be that the majority of mothers and their spouses wanted the last pregnancy and the maternal attachment levels were high. According to this result, even if the maternal attachment level of mothers is high, the traumatic events they experience do not affect the mother-infant relationship. This result is a valuable finding. Midwives and other health professionals should evaluate the attachment levels of expectant mothers starting from the pregnancy period to develop a good mother-baby attachment, which is very important for the physical and psychological development and health of babies, and attention should be paid to the mother-infant relationship in postpartum follow-ups. In addition, it is recommended to examine maternal attachment level and traumatic birth perception with larger sample groups in future studies.

As seen in Table 5, in which maternal attachment and traumatic birth perception levels of the mothers are compared with their sociodemographic and obstetric characteristics, a statistically significant difference was found only between the mothers' perception of income status and maternal attachment level $(p=0.041)$. No statistically significant difference was found between other variables and the maternal attachment and traumatic birth perception levels of the mothers $(p \geq 0.05)$ (Table 5). Surprisingly, mothers with low-income perceptions have higher attachment levels. There is a statistically significant difference between the baby's ability to distinguish its mother from strangers and the maternal attachment level $(\mathrm{p}<0.048)$ (Table 6). Similar to our study, Alan and Ege (2013) also found a significant difference between the baby's ability to distinguish its mother from strangers and maternal attachment. ${ }^{8}$ The baby's ability in differentiating its mother from other individuals can make mothers feel special and increase their level of attachment.

In our study, the traumatic delivery perceptions of the mothers who had "below the expected level" of fear, anxiety, pain, and postpartum pain were significantly lower than those with "expected level" or "more than expected level" of fear (Table 6). Similar to our results, Bay (2019) found a significant difference between mothers' perception of traumatic delivery and mothers' experiences of fear, anxiety, pain, and postpartum pain $(\mathrm{p}<0.05) .{ }^{16}$ Midwives and other health professionals involved in the birth process should be aware of the mothers' fears and concerns about the birth and should provide information and counseling from starting with the prenatal period to comfort the mother. In addition, they should evaluate mothers' pain in the labor and postpartum period and include necessary interventions to reduce pain in care practices.

\section{Limitations}

Study results are limited to the sample group and cannot be generalized to the general public. Another limitation is that illiterate mothers were not included in the study.

\section{CONCLUSION}

In our study, it was found that maternal attachment levels of the mothers were at a high level and their perception of traumatic birth was at a medium level. There was no significant relationship between maternal attachment level and traumatic birth perceptions of the mothers. Accordingly, the maternal attachment level and perception of a 
traumatic birth can be examined with larger sample groups in future studies. In addition, other variables related to the maternal attachment level can be compared.

\section{Declaration of Interest Statement}

The authors explained that they have not received financial support, fund or grants from other institutions for the investigation, authorship and/or publication of this material.

\section{REFERENCES}

1. İsbir GG, İnci $F$. Travmatik doğum ve hemşirelik yaklaşımları. KASHED 2014;1(1):29-40.

2. Callister LC. Making meaning: women's birth narratives. JOGNN 2004;33(4):508-518.

3. Yalnız H, Canan F, Genç RE, Kuloğlu MM ve Geçici Ö. Travmatik doğum algısı ölçeğinin geliştirilmesi. Türk Tıp Dergisi 2016;8(3):8188.

4. Serçekuş P, Okumuş H. Fears associated with childbirth among nulliparous women in Turkey. Midwifery 2009;25(2):155-162.

5. Güdücü N, Kayan BÖ, İşçi H, Başgül Yiğiter A, Dünder İ. Sezaryenle ve normal doğum yapan kadinlarda postpartum posttravmatik stres bozukluğu. JOPP Dergi 2013;5(3):114117.

6. Taşkn L. Doğum ve Kadın Sağlığı Hemşireliği. 9. Bask1. Ankara: Sistem Ofset 2009; 451-460.

7. Bilgin Z, Alpar ŞE. The relationship between maternal attachment perception of women's maternal role. Sağlık Bilimleri ve Meslekleri Dergisi 2018;5(1):6-15.

8. Alan H, Ege E. The influence of social support on maternal-infant attachment in Turkish society. Anadolu Hemşirelik ve Sağlık Bilimleri Dergisi 2013;16(4):234-240.

9. Kınık E, Özcan H. Maternal Bağlanmayı Etkileyen Faktörler ve Primiparlarda Maternal Bağlanma Durumu. J Health Pro Res 2020;2(1):47-53.
10. Kavlak O, Şirin A. Maternal bağlanma ölçeğinin Türk toplumuna uyarlanması. JHS 2009;6(1):188-202.

11. Nacar EH, Gökkaya F. Bağlanma ve maternal bağlanma konusunda bir derleme. Kıbrıs Türk Psikiyatri ve Psikoloji Dergisi 2019;1(1):50-56.

12. Uçar T, Gölbaşı Z. Nedenleri ve sonuçlarıyla doğum korkusu. İnönü Üniversitesi Sağlık Bilimleri Dergisi 2015;4(2):54-58.

13. Garthus-Niegel S, Von Soest T, Knoph C, Simonsen TB, Torgersen L, ve Eberhard-Gran M. The influence of women's preferences and actual mode of delivery on post-traumatic stress symptoms following childbirth. A population-based, longitudinal study. BMC Pregnancy and Childbirth 2014;14(1).

14. Soet JE, Brack GA, ve Dilorio C. Prevalence and predictors of women's experience of psychological trauma during childbirth. Birth 2003;30(1),36-46.

15. Faul F, Erdfelder E, Buchner A ve ark. G Power 3: A flexible statistical power analysis program for the social, behavioral, and biomedical sciences. Behav Res Methods 2007;39:175-191.

16. Bay F. Kadinlarda travmatik doğum algısı ve postpartum depresyon ile ilişkisi. Yüksek Lisans Tezi, Eskişehir Osmangazi Üniversitesi Sağlık Bilimleri Enstitütsü Ebelik Anabilim Dalı, Eskişehir; 2019. p. 45.

17. Muller ME. A questionnaire to measure mother- to- infant attachment, J Nurs Meas 1994;2(2):129-141.

18. Alpar R. Uygulamalı Istatistik ve GeçerlikGüvenirlik. 1. Bask1. Ankara: Detay Yayincilik; 2010. p. 130-134.

19. Şen S. Anneanne-anne-bebek bağlılığının incelenmesi. Yüksek Lisans Tezi, Ege Üniversitesi Sağlık Bilimleri Enstitüsü Doğum ve Kadın Hatalıkları Hemşireliği, İzmir; 2007. p. 72-74.

20. Şahin M. Gebelerde travmatik doğum algısı ve anne bağlanması ilişkisi. Yüksek Lisans Tezi, Ordu Üniversitesi Sağlık Bilimleri Enstitüsü Hemşirelik Anabilim Dalı, Ordu; 2020. p. 3032. 